\title{
EMERGENCE OF SIMULATIONS FOR MANUFACTURING LINE DESIGNS IN JAPANESE AUTOMOBILE MANUFACTURING PLANTS
}

\author{
Minh Dang Nguyen \\ Soemon Takakuwa \\ Graduate School of Economics and Business Administration \\ Furo-cho, Nagoya University \\ Chikusa-ku, Nagoya, Aichi 464-8601, JAPAN
}

\begin{abstract}
The aim of this research is to introduce the reader to a new perspective on the framework for designing a manufacturing line project in Japanese automobile manufacturing plants. All manufacturing aspects, manual, automated and hybrid manufacturing lines are considered; however, which line should be used for the factory is always under investigation within the factory. Simulation studies that include resource utilization, line productivity and manufacturing costs help to identify the most suitable manufacturing line type within a factory. By utilizing simulation studies, designers can make reliable decisions upon suitable manufacturing lines faster than conventional methods based upon engineering experience. In order to understand the framework of manufacturing line design, a project to design a new automobile component manufacturing line was investigated in this study, and the chosen manufacturing line was also checked by the manufacturing activities in the factory.
\end{abstract}

\section{INTRODUCTION}

Manufacturing lines play a critical and valuable role in the manufacturing system. Developing an efficient manufacturing line and bringing it to realization is the main task of manufacturing line designers. After conducting interviews with several Japanese automobile manufacturers, it was realized that manufacturing lines were traditionally designed following conventional methods that for the most part were based on engineering experience and simple calculations of worker utilization, machine utilization and line productivity with constant processing data. Simulations were not used in manufacturing line investigations.

The objective of this research is to introduce a new perspective upon the framework of designing a manufacturing lines in the Japanese automobile plants. Likewise, this research will introduce the methodology of how these simulations were used for investigating design processes via case studies covering design of new welding manufac- turing lines of "Company A" for a vehicle component project. The project was completed by a project team led by the author in three years and handed over to the factory in 2007.

The structure of this research paper follows: Section 2 will propose the framework of all design process flows for carrying out a manufacturing line design. Section 3 covers a brief literature review, Section 4 will provide results from a case study in designing a new welding line and Section 5 will conclude the paper.

\section{FRAMEWORK FOR MANUFACTURING LINE DESIGN}

The general concept and process for manufacturing line design projects are introduced in Figure 1. The content of this concept is explained in the following section.

\subsection{New Project Information}

The following information for the project are given to designers:

1. Product drawing.

2. Production volume.

3. Product model life.

4. Takt time of the manufacturing line (takt time is the maximum time which should be taken to produce one unit).

With this information, the manufacturing line development can begin.

\subsection{Make or Buy}

Based on project information, the make or buy process is investigated carefully. Make refers to made in-house and Buy refers to a product sent to an outside manufacturer. Make or Buy decision involves discussions with various related divisions in the company. The make or buy study process is divided into three following stages. 


\section{Nguyen and Takakuwa}

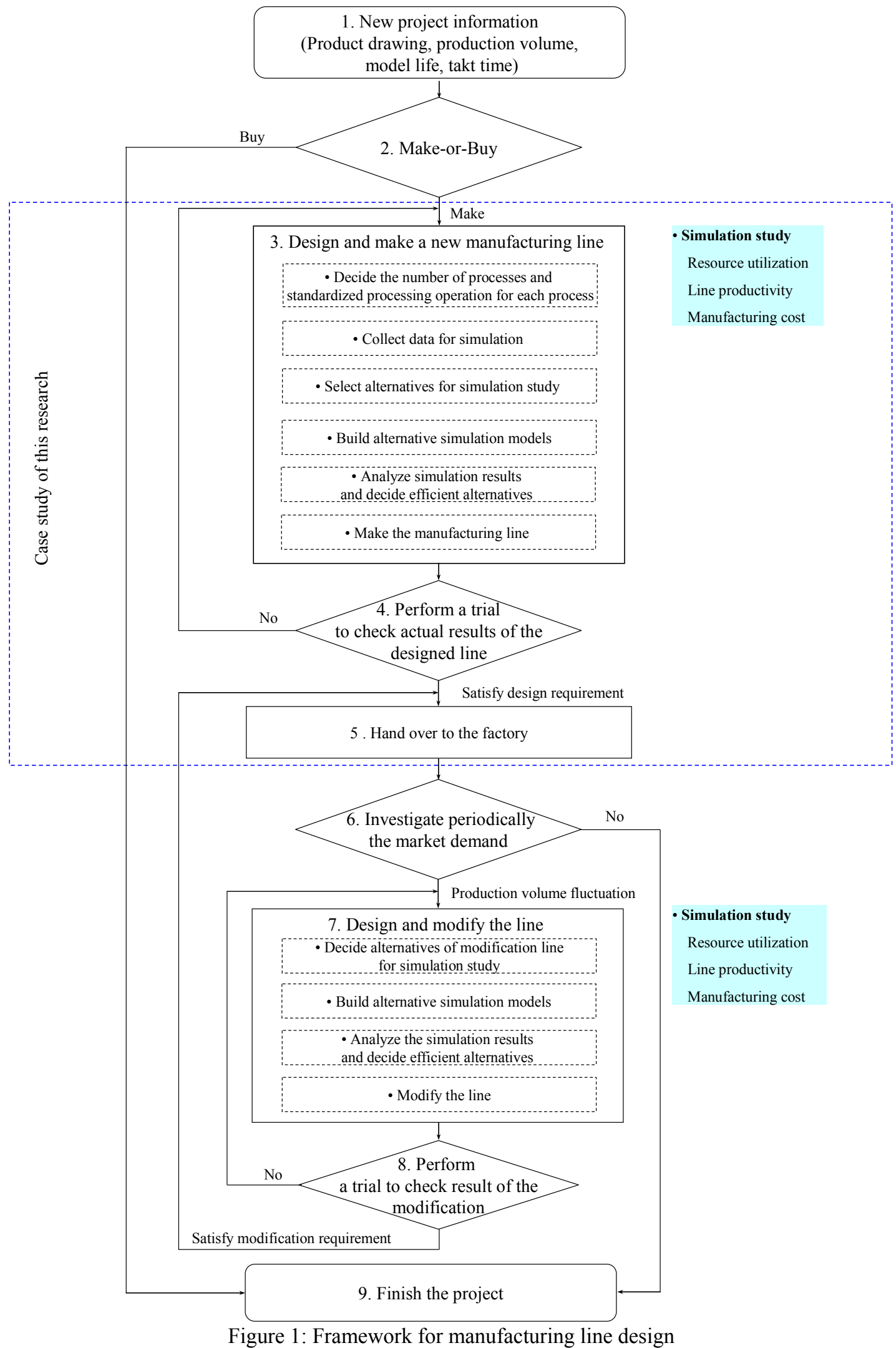

Figure 1: Framework for manufacturing line design 
Based on the product strategy of the company, the core product defines the business but if the product is not at the core it is bought from a chosen supplier.

In cases where the manufactured goods are core product, designers will study several suppliers for making appropriate benchmark comparison.

The study of manufacturing costs involved a comparison with supplier costs (in this stage, manufacturing costs were estimated based on data from previous projects). When supplier costs are cheaper and there is no threat of future competition, the product will be bought from an appropriate supplier. If not, it must be made inside the company.

In the case of a Buy decision, the manufacturing line design project will conclude, otherwise the project will progress to the next process.

\subsection{Design and Make a New Manufacturing Line}

Manufacturing line design is developed through a simulation process. Resource utilization, line productivity and manufacturing cost are all considered for developing the most efficient line. In a manufacturing line design project, manufacturing line productivity is calculated as a ratio of actual output multiplied by the takt time over the total operation time. This design process for new manufacturing lines was carried out in the following steps:

Decided upon the number of processes and standardized processing operations: these are chosen based on empirical know-how of the company, manufacturing technology, quality and technical requirements of the product.

Collected data for the simulation: data from standardized processing operations for both manual and automated process is collected from existing pilot lines (a pilot line is a line used for simulating every single standardized processing operation for a new project). Pilot project teammembers join to simulate and measure standardized processing operations for both manual and automated processing times. Data for cost simulation was collected from the company.

Selected alternative options for the simulation study: the main factors for deciding alternatives for the manufacturing line were the amount of workers and the type of equipment used. We investigated a manual manufacturing line with a manual processing machine, an automated production line with an automated processing machine and the hybrid line with both automated and manual machines. The manual line was advantageous in simplicity and having lower investment for equipment costs; however, the line used more human resources than the automated line.

Built a simulation model: simulation models of all alternatives constructed based on information of data collection in the above mentioned steps.
Analyzed simulation results and decided the efficient alternatives: the simulation was analyzed based on the target of maximization of utilization of machine and workers, maximization of line productivity (company requirement is higher than $90 \%$ ), and minimum manufacturing cost.

The chosen manufacturing line was constructed for trial to check the feasibility of the line.

\subsection{Check Actual Results of the Designed Line and Hand Over to the Factory}

Production engineers and pilot members joined to run the trial for checking the lines feasibility. Worker utilization, machine utilization, and line productivity were measured and compared with simulation results.

If the line satisfied a given design target, it was handed over to the factory, otherwise it was re-modified until a satisfactory result was achieved.

\subsection{Investigate the Market Demand for the Product}

The market demand for the product is surveyed periodically by the marketing division. In case of a decrease in production volume, takt time and a numbers of workers on the manufacturing line should be adjusted. In case production volume increases above the capacity of the production line, the manufacturing line will be modified to ensure the capacity.

\subsection{Design and Modify the Line}

Design of the modification process was carried out by the following steps:

Decided upon alternatives to modify the line including a study of alternatives of reallocation of resources, the increase or decrease of the number of machines.

Built the simulation model: simulation model of the alternatives constructed base on data collection in the current line.

Analyzed simulation results and decided efficient alternatives.

The chosen manufacturing line was modified from the current line.

\subsection{Check the Modifications and Re-Hand Over to the Factory}

Worker, machine utilization and line productivity were measured to re-confirm the feasibility of the line. If the modifications satisfied design targets the manufacturing was handed over to the factory, otherwise it was modified again until achieving positive results. 


\section{Nguyen and Takakuwa}

When a manufacturing line is handed-over to the factory after a positive modification, the design process has been concluded.

\section{BRIEF LITERATURE REVIEW}

Approaches related to manufacturing system design using simulation studies includes the following research:

Research converting an existing manufacturing system to new system: for this type of study, the concept of manufacturing method was almost changed. Dyck and Johnson (1988) studied simulation in an attempt to gradually transform US traditional manufacturing systems into more productive just-in-time applications. Simulation study in the analysis of the conversion from a job shop to a cellular manufacturing system was mentioned (Durmusoglu 1993). Feasibility of converting an existing system to a cellular manufacturing system by simulation study was presented (Taj et al. 1998).

Research in re-designing an existing manufacturing system without changing manufacturing method: such studies concentrated on only redesigning the manufacturing system. For example, simulation of production capacity of a shock absorber assembly line was studied to propose a modification of the current line (Gujarathi, Ogale, and Gupta 2004). Redesign of an injector assembly and calibration production was discussed (Grimard and Marvel 2005). Conversion from central storage to decentralized storage in cellular manufacturing environments using activity-based costing was presented to reduce total cost of storage (Satoglu, Durmusoglu, and Dogan 1993).

Research in analyzing concrete factors in a manufacturing system: the purpose of analyzing some concrete factor of manufacturing system was to improve the current system. Roser, Nakano, and Tanaka (2001) studied a method for detecting the bottleneck in a manufacturing line. Duanmu and Taaffe (2007) attempted to improve throughput of a manufacturing line using a combination of takt time and simulation analysis. Simulation of robotic welding system was investigated to show the impact of system failures and delays on the output and cycle time (Williams and Chompuming 2002). Man-machine ratios using simulation was studied to gain high resource utilization and output (Ong 2007).

However, we were unable to locate literature specifically regarding the design of a new manufacturing line from the beginning stage with initial information of the product. Furthermore, previous research has not provided an idea of where and when simulation study was utilized in the whole design process.

The first contribution of our research was to present the new framework of a design process throughout the whole product model life from practical point of view in Company A. The second was to introduce an empirical design project of a new manufacturing line for ensuring the framework and understanding the important role of simulation studies in making decisions for the most efficient line.

\section{CASE STUDY OF A NEW MANUFACTURING LINE DESIGN}

In this section, an example of designing a new manufacturing line in Company A will be introduced for further understanding of how simulation is utilized in the whole design process.

\subsection{New Project Information}

The Production Planning Division requested the design of a new cellular welding manufacturing line for producing a crucial component for vehicles. Product drawing was released from product designer and other project information of the project were quoted as follows:

1. Production volume: 9200 units/month.

2. Product model life: 6 years.

3. Takt time: 107 seconds.

Production line will follow the just-in-time manufacturing method in which parts were fed into the system at a constant rate by the Kanban (Monden 1983).

\subsection{Decide Number of Processes and Standardized Processing Operation for Each Process}

The number of processes for the required manufacturing line was decided based on the information within the project such as the welding sequence, arc welding length, number of spot weld, quality consideration, takt time, production engineering standard, and equalization of welding workload for each process. For this project, six processes were defined. As shown in Figure 2, process 1 was a nut weld that used part 1 welding with nuts, process 2 was the arc weld that used part 2 welding with the subassemblies from process 1 . Process 3 was a spot weld that used part 3 welding with sub-assemblies from process 2. Process 4 was an arc weld that used sub-assemblies from process 3 and welded with part 4, process 5 represented an additional spot weld, and process 6 was the final check and repair.

Standardized processing operation for workers and machine for each process was also decided based on the manufacturing standards of the company. As shown in Table 1, the worker conducts manual work; such as, loading parts onto a jig, sliding finished parts from of the present process to the next process, operating a manual welding machine, and checking and repairing parts. The automated process is operated by robot. 


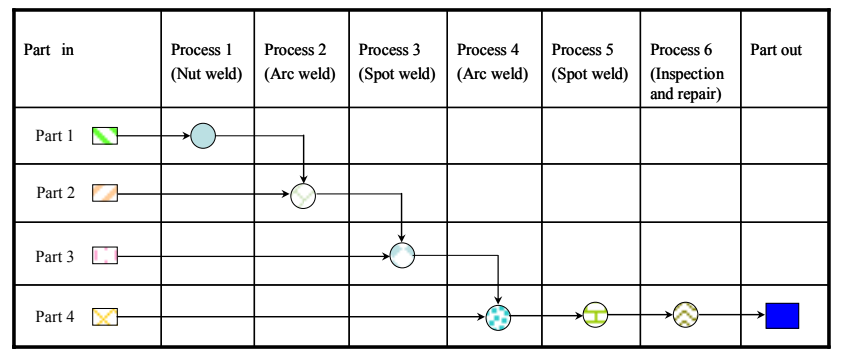

Figure 2: Number of processes of the welding line

\subsection{Data Collection}

Pilot project team-members joined to simulate actual standardized processing operation and measuring processing times.

Besides the operation time, the following schedule and data of the manufacturing line was also obtained from the factory used in the simulation inputs:

- There were two production work shifts of eight hours for each shift.

- In each shift, the worker has one hour for a meal and two 15-minute tea-breaks.

- Average unplanned failure of manufacturing line such as machine failures were estimated from past data in the factory.
- Repair rates in the final check process was also estimated to $5 \%$ quoted from past data of the factory.

The sample size of every single standardized processing operation was 50 . The final results of collected data is summarized in Table 2.

Table 1: Standardized processing operation

\begin{tabular}{|l|c|c|c|c|c|c|}
\hline $\begin{array}{l}\text { Standardized } \\
\text { Processing } \\
\text { operation }\end{array}$ & $\begin{array}{c}\text { Process } \\
1\end{array}$ & $\begin{array}{c}\text { Process } \\
2\end{array}$ & $\begin{array}{c}\text { Process } \\
3\end{array}$ & $\begin{array}{c}\text { Process } \\
4\end{array}$ & $\begin{array}{c}\text { Process } \\
5\end{array}$ & $\begin{array}{c}\text { Process } \\
6\end{array}$ \\
\hline $\begin{array}{l}\text { Load part on jig } \\
\text { (by worker) }\end{array}$ & 1 & 1 & 1 & 1 & 1 & 1 \\
\hline $\begin{array}{l}\text { Slide finished } \\
\text { part to next process } \\
\text { (by worker) }\end{array}$ & 1 & 1 & 1 & 1 & 1 & 1 \\
\hline $\begin{array}{l}\text { Arc weld } \\
\text { (by worker or } \\
\text { robot) }\end{array}$ & 1 & 1 & 1 & 1 & 1 & 1 \\
\hline $\begin{array}{l}\text { Spot weld } \\
\text { (by worker or robot) }\end{array}$ & & & & & & \\
\hline $\begin{array}{l}\text { Nut weld } \\
\text { (by worker or } \\
\text { robot) }\end{array}$ & & & & & \\
\hline $\begin{array}{l}\text { Check and repair } \\
\text { part } \\
\text { (by worker or } \\
\text { robot) }\end{array}$ & & & & & & \\
\hline
\end{tabular}

Table 2: Standardized processing operation time (seconds)

\begin{tabular}{|c|c|c|c|c|c|c|c|}
\hline & & $\begin{array}{l}\text { Process } 1 \\
\text { (Nut weld) }\end{array}$ & $\begin{array}{l}\text { Process } 2 \\
\text { (Arc weld) }\end{array}$ & $\begin{array}{l}\text { Process } 3 \\
\text { (Spot weld) }\end{array}$ & $\begin{array}{l}\text { Process } 4 \\
\text { (Arc weld) }\end{array}$ & $\begin{array}{l}\text { Process } 5 \\
\text { (Spot weld) }\end{array}$ & $\begin{array}{c}\text { Process } 6 \\
\text { (Inspection and } \\
\text { repair) } \\
\end{array}$ \\
\hline \multirow{6}{*}{ 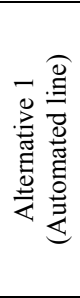 } & Load part on jig & $\operatorname{TRIA}(4,5,6)$ & $\operatorname{TRIA}(8,9,10)$ & $\operatorname{TRIA}(8,9,10)$ & $\operatorname{TRIA}(8,9,10)$ & $\operatorname{TRIA}(5,6,7)$ & $\operatorname{TRIA}(5,6,7)$ \\
\hline & $\begin{array}{l}\text { Slide finished part to next } \\
\text { process }\end{array}$ & $\operatorname{TRIA}(3,4,6)$ & $\operatorname{TRIA}(5,7,8)$ & $\operatorname{TRIA}(5,7,8)$ & $\operatorname{TRIA}(5,7,8)$ & $\operatorname{TRIA}(5,7,8)$ & $\operatorname{TRIA}(5,7,8)$ \\
\hline & Automated weld by robot & $\operatorname{UNIF}(31,33)$ & $\mathrm{UNIF}(40,42)$ & $\operatorname{UNIF}(33,35)$ & $\operatorname{UNIF}(40,42)$ & $\operatorname{UNIF}(39,41)$ & \\
\hline & Check by robot & & & & & & $\operatorname{UNIF}(30,34)$ \\
\hline & Repair by robot & & & & & & $\operatorname{UNIF}(20,30)$ \\
\hline & Worker walk in process & \multicolumn{3}{|c|}{ TRIA $(20,23,25)$} & \multicolumn{3}{|c|}{$\operatorname{TRIA}(20,23,25)$} \\
\hline \multirow{6}{*}{ 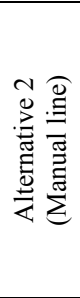 } & Load part on jig & $\operatorname{TRIA}(4,5,6)$ & $\operatorname{TRIA}(8,9,10)$ & $\operatorname{TRIA}(8,9,10)$ & $\operatorname{TRIA}(8,9,10)$ & $\operatorname{TRIA}(5,6,7)$ & $\operatorname{TRIA}(5,6,7)$ \\
\hline & $\begin{array}{l}\text { Slide finished part to next } \\
\text { process }\end{array}$ & $\operatorname{TRIA}(3,4,6)$ & $\operatorname{TRIA}(5,7,8)$ & $\operatorname{TRIA}(5,7,8)$ & $\operatorname{TRIA}(5,7,8)$ & $\operatorname{TRIA}(5,7,8)$ & $\operatorname{TRIA}(5,7,8)$ \\
\hline & Manual weld by worker & $\operatorname{TRIA}(48,50,53)$ & TRIA $(58,60,63)$ & TRIA $(50,51,54)$ & TRIA $(57,59,62)$ & TRIA $(59,61,63)$ & \\
\hline & Check by worker & & & & & & $\operatorname{TRIA}(36,43,47)$ \\
\hline & Repair by worker & & & & & & $\operatorname{TRIA}(15,20,35)$ \\
\hline & Worker walk in process & $\operatorname{TRIA}(2,3,4)$ & $\operatorname{TRIA}(2,3,4)$ & $\operatorname{TRIA}(2,3,4)$ & $\operatorname{TRIA}(2,3,4)$ & $\operatorname{TRIA}(2,3,4)$ & $\operatorname{TRIA}(2,3,4)$ \\
\hline \multirow{6}{*}{ 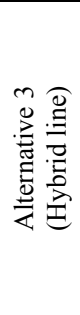 } & Load part on jig & $\operatorname{TRIA}(4,5,6)$ & $\operatorname{TRIA}(8,9,10)$ & $\operatorname{TRIA}(8,9,10)$ & $\operatorname{TRIA}(8,9,10)$ & $\operatorname{TRIA}(5,6,7)$ & $\operatorname{TRIA}(5,6,7)$ \\
\hline & $\begin{array}{l}\text { Slide finished part to next } \\
\text { process }\end{array}$ & $\operatorname{TRIA}(3,4,6)$ & $\operatorname{TRIA}(5,7,8)$ & $\operatorname{TRIA}(5,7,8)$ & $\operatorname{TRIA}(5,7,8)$ & $\operatorname{TRIA}(5,7,8)$ & $\operatorname{TRIA}(5,7,8)$ \\
\hline & $\begin{array}{l}\text { Hybrid weld by both } \\
\text { worker and robot }\end{array}$ & TRIA(48,50,53) & $\operatorname{UNIF}(40,42)$ & TRIA $(44,46,48)$ & $\operatorname{UNIF}(40,42)$ & $\operatorname{UNIF}(39,41)$ & \\
\hline & Check by worker & & & & & & $\operatorname{TRIA}(36,43,47)$ \\
\hline & Repair by worker & & & & & & $\operatorname{TRIA}(15,20,35)$ \\
\hline & Worker walk in process & \multicolumn{2}{|c|}{$\operatorname{TRIA}(6,7,8)$} & \multicolumn{2}{|c|}{$\operatorname{TRIA}(6,7,8)$} & \multicolumn{2}{|c|}{$\operatorname{TRIA}(6,7,8)$} \\
\hline \multicolumn{2}{|r|}{ Unplanned break failure } & \multicolumn{6}{|c|}{ Time to Failure: TRIA $(5400,7200,10800)$; Failure time: TRIA $(50,70,90)$} \\
\hline
\end{tabular}

Notation: TRIA=Triangular, $\mathrm{UNIF}=\mathrm{Uniform}$ 


\subsection{Select Alternatives for a Simulation Study}

The main factors for deciding alternatives for the production line were the number of workers and the kind of equipment used. In this project, we investigated three alternatives shown in Table 3: a manual production line, automated manufacturing line and the hybrid manufacturing line. The manual manufacturing line used manual welding equipments for all processes while automated manufacturing line utilized robots in all processes. The hybrid manufacturing line reflected a combination line of both manual and automated equipment. There were several options for hybrid line such as; hybrid line with one, two, three, four and five automated processes respectively. Using more automated process could save labor cost of worker on the line, however the equipment investment cost would increase. Thus, in this project, we chose a hybrid line with three automated processes aiming at an equilibrium point of labor and investment cost.

Number of worker for the three alternatives were also decided based on engineering factors such as welding sequence, arc welding length, number of spot weld, quality consideration, resource allocation and equalization of welding work for each process. As shown in Table 3, alternative one was automated line operated by 2 workers (process 1 , process 2 , process 3 were operated by worker 1 ; process 4 , process 5 , process 6 were operated by worker 2). Alternative two was a manual line operated by six workers. Alternative three was a hybrid line operated by three workers (process 1 , process 3 , process 6 were chosen as manual process due to ease of operation).

Resource utilization, line productivity and manufacturing costs were key factors in selecting the final line.
Table 3: Alternatives selecting for simulation study

\begin{tabular}{|c|c|c|c|c|c|c|c|}
\hline & Resource & Process 1 & Process 2 & Process 3 & Process 4 & Process 5 & Process 6 \\
\hline \multirow{2}{*}{ 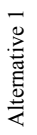 } & Machine & Automated & Automated & Automated & Automated & Automated & Automated \\
\hline & Worker & \multicolumn{3}{|c|}{ Worker 1} & \multicolumn{3}{|c|}{ Worker 2} \\
\hline \multirow{2}{*}{ 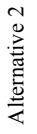 } & Machine & Manual & Manual & Manual & Manual & Manual & Manual \\
\hline & Worker & Worker 1 & Worker 2 & Worker 3 & Worker 4 & Worker 5 & Worker 6 \\
\hline \multirow{2}{*}{ 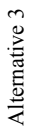 } & Machine & Manual & Automated & Manual & Automated & Automated & Manual \\
\hline & Worker & \multicolumn{2}{|c|}{ Worker 1} & \multicolumn{2}{|c|}{ Worker 2} & \multicolumn{2}{|c|}{ Worker 3} \\
\hline
\end{tabular}

\subsection{Simulation Model}

Simulation models were built using the software package Arena (Kelton, Sadowski, and Sturrock 2007). Simulation input parameters and simulation run condition were set up based on information from section 4.3. Parts were fed in to the system at a constant rate based on manufacturing takt time.

For all alternative models, the simulation run time was set to 100 working days with 100 replications.

In this project, a simulation model of each alternative was also built and executed separately due to resource differentials.

Example of an alternative 3 simulation model is illustrated in Figure 3. (In this module, worker 1 is responsible for process 1 and process 2 , worker 2 is responsible for process 3 and 4 , worker 3 is responsible for process 5 and process 6 ).

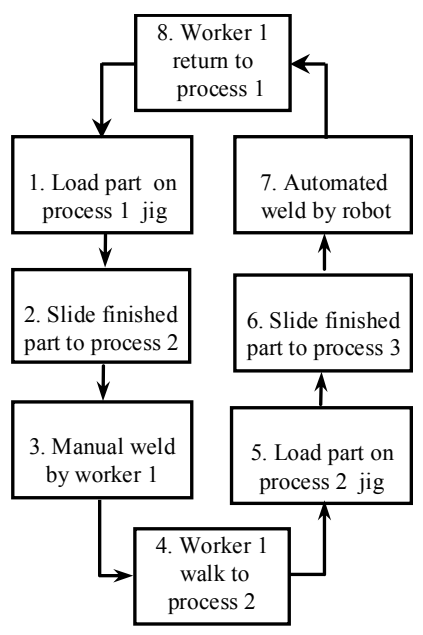

a) Worker 1

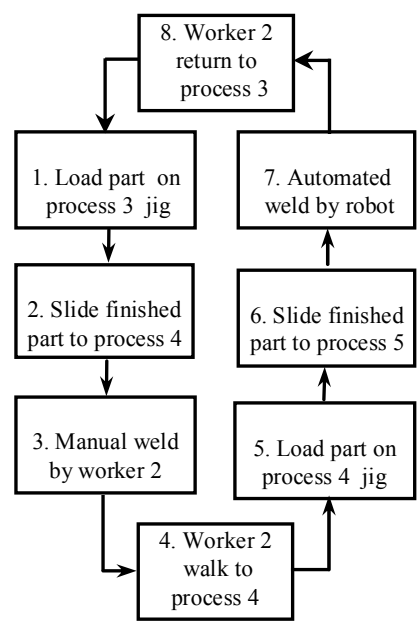

b) Worker 2

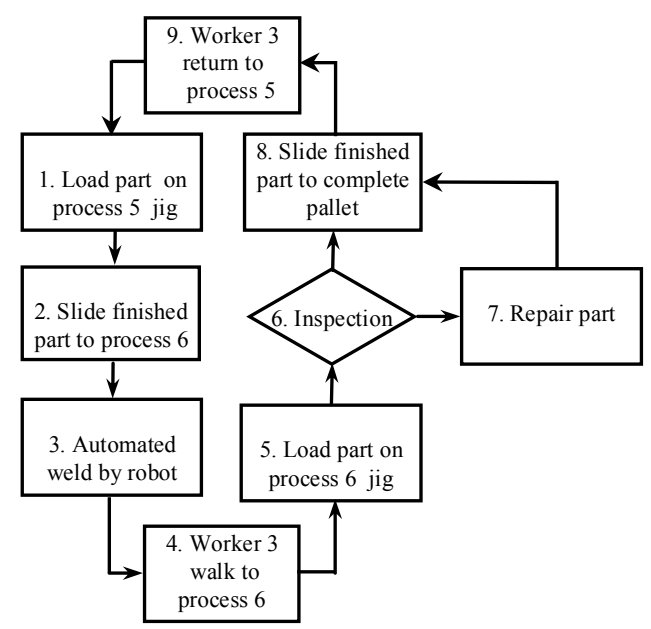

c) Worker 3

Figure 3: Sample of alternative 3 simulation module 


\section{Nguyen and Takakuwa}

\subsection{Analyze Simulation Results and Choose Efficient Alternatives}

The purpose of the simulation study for this project was to uncover which alternative satisfies the design requirements (higher resource utilization, over $90 \%$ of line productivity, and cheaper manufacturing costs). Simulation results from each of the alternative are presented as follows:

Workers utilization of each alternative is shown in Figure 4. Alternative one, the utilization of worker one was $71 \%$, worker two was $72 \%$, with average utilization of $71.5 \%$. For alternative two, the utilization of worker one was $74 \%$, worker two was $90 \%$, worker three was $80 \%$, worker four was $89 \%$, worker five was $86 \%$, worker six was $72 \%$, with a total average utilization of $81.8 \%$. For alternatives three, the utilization of worker one was $94 \%$, worker two was $99 \%$, worker three was $87 \%$, with a total average utilization of $93.3 \%$. The result showed that alternative three had highest worker utilization.

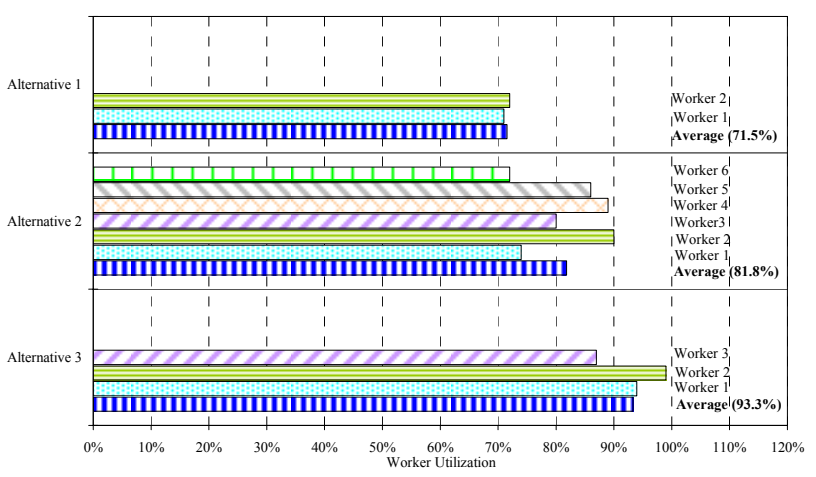

Figure 4: Worker utilization

Utilization of automated welding robots were also illustrated in Figure 5. Alternative one used six robots with average utilization of $41.8 \%$ (36\% for robot of process 1 , $47 \%$ for robot of process $2,39 \%$ for robot of process 3 , $45 \%$ for robot of process $4,46 \%$ for robot of process 5 and $38 \%$ for robot of process 6 ). Alternative three used 3 robots with average utilization of $45.7 \%$ (47\% for robot of process 2, $46 \%$ for robot of process $4,44 \%$ for robot of process 5 ). The results showed that alternative three had highest robot utilization.

Line productivity of each alternative is shown in Table 4 . Line productivity of alternative one was $99 \%$, alternative two was $98 \%$ and alternative three was $95 \%$. These results achieved the requirement of the company. The reason the automated line had a higher productivity was that the line used all robots for welding and the checking process.

Simulation results of line productivity showed that every alternative could not reach $100 \%$ productivity due to factors such as machine failures. Supposing the ideal productivity of every alternative was $100 \%$, we would find a loss of productivity in alternative one to be $1 \%$, alternatives two was $2 \%$, alternative 3 was $5 \%$. This loss in productivity needs to be transferred to economic loss; such as labor, energy, material, and inventory cost etc. in a cost simulation study.

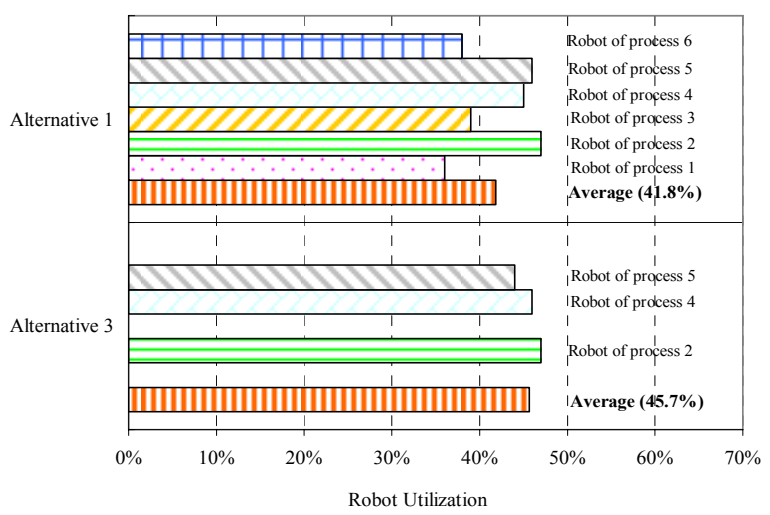

Figure 5: Robot utilization of automated process

Table 4: Productivity of the alternatives

\begin{tabular}{|c|c|}
\hline Alternative 1 & $99 \%$ \\
\hline Alternative 2 & $98 \%$ \\
\hline Alternative 3 & $95 \%$ \\
\hline
\end{tabular}

A simulation of manufacturing costs was also studied. The parameters for the simulation; such as labor costs, depreciation costs, material costs, energy consumption costs, and others cost were quoted from the Purchasing and Financing Division. The loss of line productivity for all alternatives also were considered in the calculations $(1 \%$ for alternatives one, $2 \%$ for alternative two and $5 \%$ for alternative three). The simulation result is shown in Figure 6. The manufacturing costs for producing one unit of alternative one was 76 US dollars, alternative two was 63.9 US dollars, and alternative three was 58.6 US dollars. An interesting result was also found from the cost simulation results that even though alternative three has highest lost cost $(5 \%)$, its cost was still cheapest. Other reasons for this cheaper cost were investment costs from alternative one (used robots) and labor costs of alternative two (used more workers) are more expensive than cost of alternatives three.

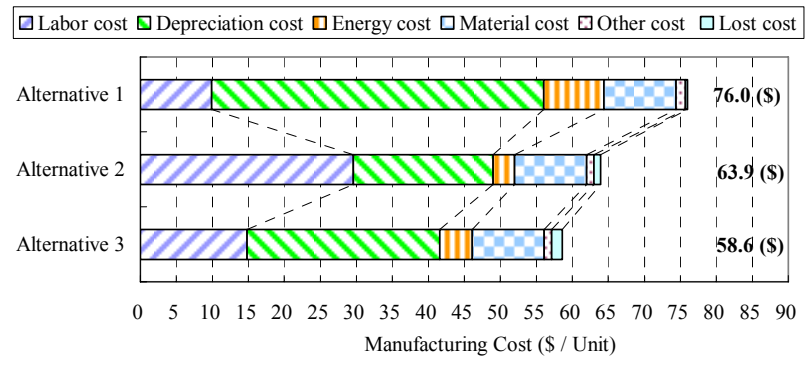

Figure 6: Comparison of manufacturing costs 
In summarizing the simulation study, alternative three (hybrid manufacture line) had a higher resource utilization and satisfied the design requirement for productivity (higher than 90\%), and cheaper manufacturing costs. Alternative three was therefore chosen for making the manufacturing line.

\subsection{Check Actual Results of the Designed Line and Hand Over to the Factory}

After deciding the manufacturing line, the equipment and robots were purchased and fabricated, and it took nearly 8 months to make the manufacturing line. After adjusting the machines, robots and parts to ensure a good quality condition, the final trial was completed by pilot members. Five working days of trials were carried out reconfirm the feasibility of the line (due to time and budget constraints, we could not run a trial as long as the simulation conditions). The average trial result of resource utilization and line productivity were shown in Table 5. Actual trial results were very close to the simulation results because of high worker skill and the actual failure time was shorter than the simulation condition. The actual results also showed that the chosen manufacturing line satisfied the design target, this line could be handed over to the factory for manufacturing activities.

The simulation was very useful in investigating the feasibility of new lines. By comparing with reference data of previous similar project quoted from the Finance Division of the company, the simulation study in this project also assisted in reducing project time in the design process $(10 \%$ of the total designed time) and save costs in line modification ( $5 \%$ of the total equipment investment cost).

Table 5: Actual trial results

\begin{tabular}{|c|c|}
\hline Resource utilization and line productivity & Result (\%) \\
\hline Worker 1 & 95 \\
\hline Worker 2 & 98 \\
\hline Worker 3 & 87 \\
\hline Robot of process 2 & 47 \\
\hline Robot of process 4 & 47 \\
\hline Robot of process 5 & 44 \\
\hline Line productivity & 96 \\
\hline
\end{tabular}

\section{CONCLUSIONS}

A framework in manufacturing line designs in Japanese manufacturing plants was introduced to show the contribution of a simulation study in the design process.

This research also introduced several positive advantages in using simulations for designing manufacturing lines. A simulation study not only can help engineers discover better options for developing efficient equipment, but also can save time and money from mistakes in redes- ign and re-fabricating equipment in comparison with conventional methods that for the most part were based on engineering experience.

The concept of a manufacturing line design in this research can be extended to all other manufacturing areas in future research.

\section{ACKNOWLEDGMENTS}

The authors would like to thank all members from related Japanese automobile manufacturing companies for creating a favorable research environment for this study.

\section{REFERENCES}

Duanmu, J., and K. Taaffe. 2007. Measuring manufacturing throughput using takt time analysis and simulation. In Proceedings of the 2007 Winter Simulation Conference, ed. S. G. Henderson, B. Biller, M. -H. Hsieh, J. Shortle, J. D. Tew, and R. R. Barton, 16331640. Piscataway, New Jersey: Institute of Electrical and Electronics Engineers, Inc.

Durmusoglu, M. B. 1993. Analysis of the conversion from a job shop system to a cellular manufacturing system. International Journal of Production Economics 30-31:427-436.

Dyck, H., and A. J. Johnson. 1988. Transforming a traditional manufacturing system into a just-in-time system with kanban. In Proceedings of the 1988 Winter Simulation Conference, ed. M. Abrams, P. Haigh, and J. Comfort, 616-623. Piscataway, New Jersey: Institute of Electrical and Electronics Engineers, Inc.

Grimard. C., and J. H. Marvel. 2005. Validation of the Re-design of a manufacturing work cell using simulation. In Proceedings of the 2005 Winter Simulation Conference, ed. M. E. Kuhl, N. M. Steiger, F. B. Armstrong, and J. A. Joines, 1386-1391. Piscataway, New Jersey: Institute of Electrical and Electronics Engineers, Inc.

Gujarathi, N. S., R. M. Ogale, and T. Gupta. 2004. Production capacity analysis of a shock absorber assembly line using simulation. In Proceedings of the 2004 Winter Simulation Conference, ed. R. G. Ingalls, M. D. Rossetti, J. S. Smith, and B. A. Peters, 1213-1217. Piscataway, New Jersey: Institute of Electrical and Electronics Engineers, Inc.

Kelton, W. D., R. P. Sadowski, and D. T. Sturrock. 2007. Simulation with ARENA. 4th ed. New York: McGraw-Hill.

Monden, Y. 1983. Toyota Production System: Practical Approach to Production Management. 1st ed. Norcross, Georgia: Industrial Engineering and Management Press, Institute of Industrial Engineers.

Ong, H. H. 2007. Establishing man-machine ratio using simulation. In Proceedings of the 2007 Winter Simu- 
lation Conference, ed. S.G. Henderson, B.Biller, M.H.Hsieh, J.Shortle. J.D.Tew, and R.R.Barton, 16631666. Piscataway, New Jersey: Institute of Electrical and Electronics Engineers, Inc.

Roser, C., M. Nakano, and M. Tanaka 2001. A practical bottleneck detection method. In Proceedings of the 2001 Winter Simulation Conference, ed. B. A. Peters, J. S. Smith, D. J. Medeiros, and M. W. Rohrer, 949953. Piscataway, New Jersey: Institute of Electrical and Electronics Engineers, Inc.

Satoglu, S. I., M. B. Durmusoglu, and I. Dogan. 1993. Evaluation of the conversion from central storage to decentralized storages in cellular manufacturing environments using activity-based costing. International Journal of Production Economics 103:616-632.

Taj, S., D. S. Cochran, J. W. Dura, and J. Linck. 1998. Simulation and production planning for manufacturing cells. In Proceedings of the 1998 Winter Simulation Conference, ed. D. J. Medeiros, E. F. Watson, J. S. Carson and M. S. Manivannan, 973-977. Piscataway, New Jersey: Institute of Electrical and Electronics Engineers, Inc.

Williams, C.R., and P. Chompuming. 2002. A simulation study of robotic welding system with parallel and serial process in the metal fabrication industry. In Proceedings of the 2002 Winter Simulation Conference, ed. E. Yücesan, C. -H. Chen, J. L. Snowdon and J. M. Charnes, 1018-1024. Piscataway, New Jersey: Institute of Electrical and Electronics Engineers, Inc.

\section{AUTHOR BIOGRAPHIES}

MINH DANG NGUYEN is a Ph.D. candidate in the Graduate School of Economics and Business Administration at Nagoya University in Japan. He has been involved in several projects dealing with manufacturing line design using simulation studies in Japanese automobile manufacturing Plants. He received his M.Sc. degree in Mechanical Engineering at The University of Tokyo. His research interest is in the area of manufacturing line design using simulation and other economic factors, make and buy decision making, and out-source purchasing of manufacturing firm.

SOEMON TAKAKUWA is a Professor in the Graduate School of Economics and Business Administration at Nagoya University in Japan. He received his B. Sc. and M.Sc. degrees in industrial engineering from Nagoya Institute of Technology in 1975 and from Tokyo Institute of Technology in 1977 respectively. His Ph.D. is in industrial engineering from The Pennsylvania State University. He holds a Doctorate of Economics from Nagoya University. His research interests include optimization of manufacturing and logistics systems, management information system and simulation analysis in these systems including hospitals. He has prepared the Japanese editions of both the Introduction to simulation using SIMAN and Simulation with ARENA. He has been serving concurrently as a senior staff member of the Department of Hospital Management Strategy and Planning at Nagoya University Hospital. 